\title{
KUST SEE LAPS NEED LAULUd VÕTAB EHK KEELELINE SISEND JA VÄLJUND LUUBI ALL
}

\author{
Helen Kõrgesaar, Airi Kapanen
}

\begin{abstract}
Ülevaade. Artiklis arutletakse hoidjakeele ja lastekeele kvalitatiivse ja funktsioonilise erisuse üle. Peamiselt refereerivas artiklis antakse ülevaade sisendkeele olemusest ja tunnusjoontest, tuuakse esile keelelise sisendi ja väljundi sarnasused ja erinevused ning kirjeldatakse, kuidas eri faktorid mõjutavad lapsega suhtlemist, sh lapsega kõneldavat keelt.

Kuna laps omandab keele kõnekogukonnas, kus suhtlusolukorrad on erinevad ning eri vestlusosaliste fonoloogiline, morfoloogiline, süntaktiline ja semantiline pädevus isesugune, on lapsega kõneldav keel dünaamiline ja muutub lapse vanusega. Lapsega kõnelemise viisil arvatakse meie kultuuris olevat tähtis roll ja hulk keelenähtusi, mis teatud ajavahemikul esinevad lapsele suunatud kõnes, peegelduvad samal ajal ka lapse enese kõnes. Teisalt on keelenähtusi, mis on küll olemas täiskasvanu kõnes, ent ei kajastu sugugi lapse omas, mistõttu ei saa loota, et kogu sisendkeel hakkab kohe peegelduma ka lapse kõnes.

Arutletakse, kas ja kuivõrd on oluline, kuidas lapsega suheldakse, ning kas sisendkeelel on oluline funktsioon kõne arengu toetamisel.
\end{abstract}

Võtmesõnad: esimese keele omandamine, lapsele suunatud kõne, hoidjakeel, lastekeel, eesti keel

\section{Sissejuhatus}

Tavapäraselt tõlgendatakse hoidjakeelena üksnes seda kõnet, mida räägib lapsega ema, ehkki selle terminiga tähistatakse tegelikult igasugust kõnet, mida laps kuuleb, olgu siis kõnelejaks ema või mõni muu lähedane ning olgu kõne otse lapsele suunatud või mitte. ${ }^{1}$ Keeleomandamisel on laias laastus kaks osalist, kellest üks laps - võtab vastu selle, mida talle pakutakse. Pikapeale pakub laps, kes on viibinud keelelise sisendi mõjuväljas, midagi, mida nimetame keeleliseks väljundiks. Laste-ja hoidjakeeleuurimustes on hulk artikleid (nt Ninio 2011, Behrens 2006, 2009, Lieven 2010) pühendatud just hoidja- ja lastekeele vastastikmõju uurimisele, sealjuures

1 Vt autorite artiklit laste- ja hoidjakeele uurimise soovituslikest terminitest (Kõrgesaar, Kapanen 2015). Artiklis on 
on hoidjakeele ja lastekeele kõrval, toonitamaks mõlema eripärasid, kasutatud väljendit "normaalne keel" (ingl normal language), mis viitab sellele, et nii laste endi kui ka hoidjate keelekasutust tajutakse keele tavapärasest kasutusest erinevana. ${ }^{2}$

Peamine küsimus on, kas lastel ei või keeleomandamisel midagi tähtsat puudu jääda, kui nad kuulevad lihtsustatud keelevarianti, peavad suutma selle kaudu omandada komplekssed keeletasandid ja oskama neid eri suhtlusolukordades rakendada. Kui hoidjakeel on keelevariant, mis on keelt omandavale lapsele suupäraseks mugandatud, siis kuidas õpib ta sellele mugandatud keelevariandile toetudes selgeks raskemad fonoloogilised järjendid, sõnade ja väljendite sidumise viisid jm, arvestades, et sellega samal ajal peab ta õppima sõnu (ja väljendeid) voolavast kõnejadast segmentima ja ühendama sõna häälikulist vormi selle tähendusega?

Laste- ja hoidjakeeleuurijaile, samuti arengupsühholoogidele, kes on valdkonda põhjalikumalt uurinud, pole keelelise sisendi ja keelelise väljundi suhe niisama selge (vt Argus, Kõrgesaar 2014, Ninio 2011, Lieven 2010). Võib küll mõelda, et kui anname lapsele keelelise sisendi, saame tulemuseks keelelise väljundi, ent selline mõttekäik on võrdlemisi primitiivne, kuivõrd tegu pole masinate, vaid inimestega. Eric Wanneri ja Lila Gleitmani (1982: 311) väitel on hoidjakeelel küll kindlad omadused, ent need ei näita veel, et laps saab neist keeleomandamiseks tuge. Melissa Bowermanni (1987: 110) sõnul ei pea selleks, et laps keele omandaks, olema tema keelekeskkond midagi väga erilist ja pingutatut.

\section{Keelelisest sisendist}

Pim Levelt (1975: 173) on keelelise sisendi kohta öelnud, et "lapsele esitatakse miniatuurkeele grammatilist jada, mis lapse kompetentsuse kasvades süstemaatiliselt laieneb". Kui keeleomandamist on võrreldud kaljuronimisega: laps alustab, kinnitades oma kanna kusagile, ja kasutab esialgset tugipunkti, et jõuda järgmiseni (Naigles, Hoff-Gingsberg 1995: 836), siis keelelist sisendit on nimetatud tellinguteks (ingl scaffolding). See metafoor annab mõista, et tellingud (mugandatud kõne) on ajutised ja neid võidakse panna kohale, tugevdada, võtta tükkhaaval vähemaks või üldse ära. Tellingute metafoori võtsid kasutusele Donna Wood jt (1976: 191) esimese keele omandamise kontekstis, et tähistada, kuidas vanemad on lastele keele omandamise juures kui giidid või juhendajad.

Lastekeel on keelevariant, mis kasutab täiskasvanukeelega võrreldes lihtsamat keelt, ja hoidjakeel on register, mis kasutab mugandatud keelt. Suhtluse üks pool on keelt omandav inimene, teisel pool on vilunud keelekasutaja; üks veel ei oska kõneleda ja teine, saades sellest aru, mugandab oma keelekasutuse talle sobivaks. Kõne, mis on mõeldud täiskasvanult täiskasvanule, on silmanähtavalt erinev sellest, mille täiskasvanu suunab lapsele (Fernald jt 1989).

Lapsega rääkides kasutab täiskasvanu niisiis oma kõne funktsionaalset lihtsustamist, mis hõlmab süntaksi lihtsustamist, lausungi lühendamist, sõnavara piiramist, liialdatud intonatsiooni, selgemat hääldust, kordusi ja ümberütlemisi. Kõik sellised modifikatsioonid moodustavad erilise sotsiolekti, mida nimetatakse beebikõneks, lihtsustatud registriks (Ferguson 1977) või hoidjakeeleks (Newport 1976). Funktsionaalne lihtsustamine peegeldab hoidjate (ja teiste lapsega

2 Kõnekeel kuulub mittenormingulisse registrisse (vt Hennoste 2002: 243). 
kõnelejate) soovi maksimeerida nende öeldud lausungite arusaadavust (Ochs 1991: 2).

Võib näida, et uurida pole siin midagi, sest vestlusosalised, laps ja täiskasvanu, tajuvad teineteist adekvaatselt, on algusest peale orienteeritud koostööle, et suhtlus õnnestuks, ja pealegi, pole teada inimesi, kellest ühel või teisel viisil poleks saanud kõnekogukonna liikmeid, nt kurdid emad kasutavad visuaalset hoidjakeelt, mille kohta on täheldatud, et emade käemärgid on väga rütmilised ja sagedaste kordustega (Fromkin jt 2011: 367). Keele omandavad ka need lapsed, kes kasvavad sellises kultuuris, kus vanema-lapse suhtlustava on Euroopas harjumuspärasest erinev (vt lähemalt 3. ptk "Keelelise sisendi erinevus kultuuriti”). Kui nii, siis miks lihtsustab täiskasvanu lapsega rääkides oma kõnet ja tema hääletoon muutub alateadlikult kõrgemaks (Gopnik jt 1999) ja kõne aeglasemaks (Wang jt 2015), miks (enamasti) eelistab laps kuulata just hoidjakeelset kõnet (Cooper, Aslin 1990, Fernald 1985jt), miks on hoidjakeele ja laste varase kõne sõnad just kahesilbilised (Toivainen 1994, Argus 2004 jt), miks kaob osa keelevahendeid hoidjakeelest, kui laps saab vanemaks, rääkimata sellest, kuidas saab keelt alles omandav laps selgeks arbitraarse häälikujärjendi tähenduse ja oskuse seda eri kontekstides kasutada? Need ja paljud teised küsimused on laste- ja hoidjakeeleuurijatele läbi aegade huvi pakkunud ning kui ühele küsimustest ongi vastus leitud, on neid, millele vastust alles otsitakse.

Soome lastekeeleuurija Kirsti Toivainen (1994: 43-46) on leidnud, et lapsega rääkides kasutavad vanemad hoidjakeelt enim lapse esimestel elukuudel, mugandades oma kõne lapsele suupäraseks. Ta on märkinud silpide arvu kohta hoidjakeele sõnavaras, et nii ühe- kui ka kolmesilbilised sõnad mugandatakse kahesilbilisteks (nt pää > pääkkö, suu > summu; aga peukalo > peukku, orava > orkku) ja et silbipiirile jäävad kaashäälikud on enamasti geminaatnasaalid või klusiilid.

Karl Pajusalu uurimistulemused (2001: 83) lõunaeesti hoidjakeele kohta kinnitavad Toivaineni omi: enamik hoidjakeele sõnu on ühe- või kahesilbilised ja kolmesilbilistel sõnadel on sageli deminutiivtuletuslik lõpp. Pajusalu sõnul on levinuim häälikujärjestus (rohkem kui 2/5 kogu lastekeele sõnavarast) KVKKV (nt kutsu, ninnu) ja viiendiku moodustavad KVKV-tüüpi sõnad (nt kätu, punu). Ka rootslane Sven Strömqvist (1984) on väitnud, et mudel KVKV on kõigis keeltes eelistatuim hoidjasõna struktuur.

Kõnet aga ei lihtsusta lapse-täiskasvanu suhtluses mitte üksnes täiskasvanu, vaid ka laps, kelle keelekasutuses võivad nt ühe- ja kolmesilbilised sõnad hoidjakeele deminutiivide eeskujul kahesilbilisteks muutuda (Argus 2004: 25). Soome hoidjakeelest rääkides on Toivainen arutlenud, miks niigi lihtne ja suupärane, ühesilbiline sõna suu on muudetud kahesilbiliseks suukko'ks, ja Reili Argus (2008: 20, 42) on sellele küsimusele oma doktoriväitekirjas vastuse andnud, põhjendades trohheilise kõnetakti eelistamist kõnelemise loomuliku viisiga ja väites, et ka eesti laps hakkab morfofonotaktikat omandama keele kõige loomulikumatest struktuuridest. Kui laps saab vanemaks, hakkavad fonoloogilised piirangud, nagu kahesilbilisus ja suutmatus (mitte tähelepanematus) hääldada kinnise järgsilbi lõpuhäälikut, taanduma. 


\section{Keelelise sisendi erinevus kultuuriti}

Keeleline sisend ei ole midagi püsivat, see on dünaamiline. Hoidjakeelel on hulk eri vorme ja nende kasutamine sõltub mitmest faktorist, nagu vanema/lapse sugu, vanema/lapse vanus, lapse sünnijärjekord ja -kaal (vt Stolt jt 2014, Hoff-Ginsberg 1998), pere sotsiaalmajanduslik taust ning vanemate vanus ja haridustase (Réger 1990, van Houten 1986), elukoht kas linn või maa (Heath 1989) jm, ent sisendkeele tugevaimad mõjutajad on vast kultuurierisused. Need määravad, missuguse sisu annab kultuur lapse sotsiaalsele positsioonile, ja sellel on olulisim roll keelelise sotsialiseerumise protsessis (Blount 1977: 305).

Kõne ei pruugi olla vaid selleks, et mõtteid vahetada. Näiteks Aafrika põliskultuurides on kõne staatuse näitaja (Rabain-Jamin 1994: 147). Kõneleja roll on antud mõningatele eakatele kogukonna vanematele ja sedalaadi hierarhia mõjutab tervet kogukonda. Kui võrrelda Aafrikast pärit emasid prantsuse ja Ameerika emadega, siis esimesed tavaliselt ei räägi lapsega, vaid nende eest. Kui laps on suurem, suunatakse teda pigem verbaalselt, mitte pilkudega.

Aafrika kultuurides ei lisata sõnadele kasvatuslikku varjundit ega kasutata neid parasjagu toimuva tegevuse organiseerimiseks, vaid tähelepanu pööratakse sotsiaalsete suhete määramisele ja konstrueerimisele (vt nt Bonvillain 2003, Schieffelin 1985, Ochs, Schieffelin 1994 jt, allpool). Selmet selgitada mõne eseme kasutamist, selle ülesandeid ja võimalusi, nagu Euroopa ja Ameerika kultuuris kombeks, on kung-ekoka ja soninke ema-lapse mõttevahetuse sõnad kasutusel hoopis selleks, et rõhutada asjade vahendusel võimalikuks saavat sotsiaalset tegevust. Ka kolmekuustele imikutele näidatakse, et tähtis on just inimestele orienteeritus ja suhtluseks avatud olek (Rabain-Jamin 1994: 156).

Kaluli kogukonnas ${ }^{3}$ on tavaks hakata lapsele keelt õpetama niipea, kui laps ütleb oma esimesed sõnad (aga mitte varem). Täiskasvanud usuvad, et lapsed õpivad enamiku käitumist teisi jälgides ja samamoodi õpitakse ka keelt: seda tuleb lapsele näidata (Bonvillain 2003: 266). Nii loovadki kaluli emad kõneolukorra, kus püütakse jäljendada väikelapsele suunatud kõnet ehk last presenteeritakse kui kõnelejat, mitte kui kõne autorit (Schieffelin 1985, Ochs, Schieffelin 1994: 84).

Suuremalt kaluli lapselt oodatakse, et ta kordaks täiskasvanu lauset. Kui täiskasvanu avaldab arvamust, ütleb ta selle lõpus elema 'ütle samamoodi'. Nii on kaluli laps sunnitud keelt õppima üksnes täiskasvanulike lausungitega, ilma et tal oleks võimalust luua lapsepäraseid. Elema-sõna kasutavad hoidjad (tavaliselt emad) nii poiste kui ka tüdrukutega kuni 3. eluaastani ja seda kasutavad pisikesed tüdrukud ka ise, kui suhtlevad endast veelgi noorematega. Tüdrukuid õpetatakse juba väga varajasest vanusest võtma vastutust hoidjana, ent kuna poistelt seda ei oodata, on nad elema-rutiini kaasatud kui vastuvõtjad, mitte kui algatajad. (Schieffelin 1985, 1990)

Lääne-Samoa kultuuris ei hakatagi täpsustama ega uurima, mida laps püüab öelda, vaid talle tehakse selgeks, et temast ei saada aru. Lapsed osalevad kogukonna elus kui teiste inimeste lihtsustamata kõne pealtkuul(a)jad. (Ochs, Schieffelin 1994: 82-83) Luo ja samoa lapsed ei kuule oma vanematelt peaaegu mingisugust sisendkõnet, mida võiks tõlgendada kui märki sellest, et neid peetakse arvestatavaiks suhtluspartnereiks. Neile saab osaks hulk käske ja küsimusi, mis ei ole peaaegu kunagi jah/ei-küsimused (st lapse eelistust ei küsita kunagi). (Blount 1977: 304)

3 Kaluli on väike, aiandusega tegelev kogukond Uus-Guineas, kaluli keel kuulub bosavi keelte hulka ja keele kõnelejaid on 1994. aasta andmetel u 2500. 
Ka Lõuna-Ameerika kultuuride hulgas leidub rahvaid, kus lapsega hoidjakeelt ei räägita. Nii maajade kui ka kitšede juures on suuline suhtlus lapse ja vanema vahel peaaegu olematu ja lapsi hakatakse vestluspartnereina arvestama alles siis, kui nad on õppinud rääkima (Lieven 1994, Pye 1986, 1992: 242-243). Lieveni sõnul näitas uurimus, milles vaadeldi maaja lapsi (Gaskins 1999), et lapsed veetsid üsna samapalju aega mängides ja suheldes nagu Euroopa-Ameerika lapsedki, ent maaja lastel olid need kaks tegevust täielikult eraldi: nad ei suhelnud mänguasjadega mängimise ajal peaaegu kunagi teiste inimestega ja ka täiskasvanud ei kasutanud sotsiaalses suhtluses väikelastega üldse mänguasju. (Lieven, Stoll 2013: 181) Kui Ameerika keskklassi inimeste lapsi koheldakse kui isikuid, kellel on õigus, et neid kuulataks - ka siis, kui nende kõne pole arusaadav -, siis inuiti (Crago, Shanley 1998: 210-211) ja varlpiri4 (Bavin 1992: 327) väikelaste häälitsusi enne teist eluaastat ei tõlgendata kui kõnet ja seepärast ei pöörata laste vokaalsetele katsetustele tähelepanu ega tõsteta isegi pilku.

Atapaski $^{5}$ kogukonnas, kus täiskasvanute respekteerimist väga hinnatakse, peavad lapsed infot hankima, ilma et küsiksid seda täiskasvanult otse (Scollon 1982: 87). Hawaii põliselanikud arvavad samamoodi ega julgusta lapsi küsimusi esitama. Stephen Boggs (1985: 55) märgib, et lapsed, soovides saada vastust, peavad küsimuse küsima mitu korda, nad sõnastavad seda teisiti, võivad isegi veidi valetada, kui ootavad, et vanem vastaks. Vanem ei vasta aga kohe, kui ta seda üldse teeb. Ka inuiti naised väidavad, et neile ei meeldi, kui lapsed küsivad täiskasvanult küsimusi (Crago jt 1993).

Eelnenust on näha, et üldiselt jagunevad kõnekogukonnad kaheks: ühed on lapsele suunatud, teised mitte. Esimestes peetakse last sünnist saati aktiivseks suhtlejaks, vestluskaaslaseks, ja täiskasvanu võtab lapse kõnelema õpetamisel aktiivse rolli. Teised kultuurid ei kaasa last vestlusesse enne, kui ta on rääkima õppinud, ja täiskasvanu ei võta lapse kõnelema õpetamisel aktiivset rolli. Need kaks lähenemist mõjutavad sisendkeele olemust ja selle olemasolu üldse: esimesena nimetatud kõnekogukonda kuuluvad lapsed kuulevad oluliselt lihtsustatud kõnet, teise kultuuri lapsed on aga enamasti pealtkuul(a)jad, keda teatud vanuseni kõnekogukonna liikmetena ignoreeritakse. Mõlemal juhul oskavad lapsed siiski enne kaheaastaseks saamist grammatilistest konstruktsioonidest aru saada ja neid produtseerida (Ochs, Schieffelin 1994: 80).

\section{Keelelise sisendi muutumine lapse kasvades}

Konstruktivistliku keelekäsitluse järgi on grammatika omandamine protsess, mida toetab teatud keelenähtuste või struktuuride sagedus, esilduvus ja läbipaistvus sisendkeeles (Argus 2004: 23). Laps peab grammatika ise konstrueerima ning kasutab selleks keelekeskkonnast saadud mudeleid ja eeskujusid. Keel omandatakse etapiti ja iga etappi piiritleb vanusevahemik, mille jooksul laps mingi keelekategooria omandab.

Suure osa keelenähtuste kohta võib öelda, et hoidjakeele erijooned peegelduvad dünaamiliselt lapse kõnes. Sisendkeele põhimõjutaja, pere kultuuritausta kõrval on teine sama oluline seda sisendit mõjutav asjaolu lapse vanus, kuivõrd

\footnotetext{
4 Varlpiri kuulub pama-njunga keelte hulka, seda kõneldakse Austraalias Põhjaterritooriumil ja keele kõnelejaid oli 2006. aasta andmeil 2500-3000.

5 Atapaski keeled - 44 indiaani keelest koosnev atapaski-ejaki keelkond. Tuntuimad on apatši ja navaho keel.
} 
hoidjakeel, mida kõneldakse aastase, 4-aastase või 10-aastase lapsega, ei ole üks ja seesama.

Eesti hoidjakeeleuurimused (Argus 2004, Kõrgesaar 2008) on näidanud, et varajasele hoidjakeelele on iseloomulik helijäljenduslike sõnade, imitatiivide ja deminutiivtuletiste rohkus, kuid nende hulk vanema kõnes väheneb lapse vanuse kasvades. Umbes 18 kuu vanuse lapsega kõneldes on hoidjakeeles alles jäänud vaid üksikud helijäljenduslikud sõnad, imitatiivid on hoopis kadunud. Sama nähtus leiab paralleelselt aset ka lapse kõnes, mis hakkab üha enam sarnanema täiskasvanu omaga. 2014. aastal tehtud laste- ja hoidjakeele uurimuse (Argus, Kõrgesaar 2014) tulemused näitasid, et ka sõnaliikide jaotumise poolest on juba 2 aasta ja 3 kuu vanuse lapse sõnavara täiskasvanu omaga sarnane. Kahe lapse ja vanema keeleandmed tõid selgelt esile, kuidas vanemate kõne individuaalsed eripärad peegelduvad ka laste kõnes (nt nimi- ja tegusõnade osakaal, perifrastiliste tegusõnade hulk jm). Samasugune tulemus on saadud ka saksa laste- ja hoidjakeelt uurides (Kauschke, Hofmeister 2002: 6).

Anat Ninio (1992) kirjeldab, et nii lapse kui ka ema ühesõnalausungid väljendavad samu suhtluseesmärke. 24 pooleteistaastase heebrea lapsega tehtud uuringust selgus, et 97\% lapse lausungitest olid varem ka emad kasutanud sama suhtluskavatsuse väljendamiseks. Suurima tõenäosusega võttis laps omaks kõige sagedamini kuuldud mallid ja tõenäosus kasutada vähekuuldud malle kahanes üliväikeseks. Ninio leiab, et laste ühesõnalausungid on ema omadega väga sarnased ja ilmselt neilt õpitud.

\section{Erinevused sisendis ja väljundis}

Keelelist sisendit, nagu mainitud, saab laps nii oma vanematelt ja lähedastelt kui ka kõikjalt mujalt enese ümbert. Keeleline sisend mõjutab lapse kõne arengut ühel või teisel moel. Kuna laps on keeleomandamisel aktiivselt tegutsev subjekt, tekib kõneolukordi, kus keeleline sisend ja keeleline väljund pole sugugi identsed - vale on väita, et laps kordab järele täpselt just seda, mida kuuleb. Kahe keelevariandi erinevusi keele omandamise eri etappidel põhjustab mitu aspekti, mille üle arutleme artikli siinses osas.

Praegusaja laste- ja hoidjakeeleuurimises ollakse enamasti seisukohal, et mis tahes keelelise sisendi tähtsus on vaieldamatu, kuid selle vajalikkuse ja asendamatuse (Newport jt 1977, Lieven jt 2003, Tomasello 2005, Ninio 2011, Soderstrom, Wittebolle 2013) rõhutamise varju on jäänud tõsiasi, et keeleline sisend ei hõlma keelelist väljundit ehk teisisõnu pole võimalik öelda, et laps esitab täpselt ja ainult sellist keelekasutust, mida ta iga päev enese ümber kuuleb (ja millest ta alati aru saab). Hoidja-ja lastekeele suhe pole ühesuunaline - vanemalt lapsele. Keeleomandamisprotsessis on igas vanuses laps ka ise aktiivne osaline, mis tähendab, et ühelt poolt ta valib keeleüksusi, mida verbaliseerida ja suhtluses kasutada, teisalt on tema valikute taga kognitiivne küpsus. Avastatud on ka, et samavõrra kui vanema kõne mõjutab last, mõjutab lapse kõne ka vanema oma (Newport jt 1977: 112), ja hoidjakeele dünaamilisus on tingitud lapsest, st keelelisest väljundist.

Keeleomandamine on rikkalikku hoidjakeelt arvestades aeglane (Behrens 2006: 22). Ninio (2011: 167) sõnul võib lapsel olla samasugune süntaktiline süsteem 
nagu nende vanemail, kuid neil on see väiksem. Ta leiab, et vaatamata lapse ja vanema kõne väga suurele sarnasusele, on selles ka olulisi erinevusi, mis viitavad, et lapse õppimist mõjutavad ka pragmaatilised faktorid ehk valikud, mida mingis kindlas olukorras öelda.

On leitud (Kõrgesaar 2008), et lapse ja täiskasvanu küsimused kannavad eri suhtluseesmärke. Laps kasutab küsimusi peamiselt selleks, et infot saada, täiskasvanule pakub küsilausung aga arvukalt muid võimalusi, nt lapse öeldut kinnistamise eesmärgil korrata, seda täpsustada või parandada, vestlust algatada ja juhtida, tähelepanu tõmmata, teemat vahetada või laiendada. Teisisõnu valdab täiskasvanu pragmaatikat lapsest paremini. Eesti hoidjakeeleuuringu tulemused (Kõrgesaar 2014a: 199) on näidanud, et lapsele vanuses 1;8-2;8 suunatud kõnes oli vaid 1,3\% täiskasvanu küsimusi sellised, millega sooviti midagi teada saada (infot otsivad küsimused). Siit võib järeldada, et suur roll lapse ja täiskasvanu kõne erinevuses on just pragmaatikal - lapsel ei olegi tarvis kasutada kõiki neid keelevahendeid, mida vanemal. Laps ja täiskasvanu on suhtlusolukorras eri osalised ja vajavad seetõttu ka mõnevõrra erinevaid keelevahendeid.

Üks lapse enimkasutatud keelevahend on nimisõna. Sõnaliigiuuringust (Argus, Kõrgesaar 2014: 46-48) selgus, et keeleomandamise varases staadiumis (vanuses 1;3-2;3) on eesti laste kõne võrdlemisi nimisõnakeskne. Aasta jooksul see nimisõnakesksus pisut väheneb, kuid ei saa väita, et selle on põhjustanud sarnane suundumus sisendkeeles. Nimisõnakesksust on tähele pannud ka teised: Ninio (2011: 168) on väitnud, et lapsed eelistavad kasutada vähem verbe ning valivad neist oma kõnesse lühemad ja lihtsamad, Behrens (2006: 16) kinnitab, et lapsed alustavad nimisõnadest ja teistest muutumatutest elementidest.

Keelelise sisendi kohta on harjutud mõtlema, et see on midagi ideaalset ja üsna täiuslikku (Newport jt 1977). Loomulikult on täiskasvanu kõne võrrelduna keelt omandava lapse keelevariandiga mitmel keeletasandil palju mitmekesisem ja komplekssem, kuid see asjaolu ei tee hoidjakeelest veel täiuslikku keelevarianti. Keel, mida laps kuuleb, on sageli struktureerimata ja väljajätteline (Fromkin jt 2011: 331). Lisaks kuuleb laps ka muud peale otse temale suunatud kõne: täiskasvanute omavahelist vestlust, vanema vestlust pere suuremate lastega, kõnet kodust väljaspool, telerist kostvat kõnet jm. Niisiis iseloomustavad kõnet, mida laps päevast päeva kuuleb, keelevääratused, valestardid, ebagrammatilised ja väljajättelised (ka lõpetamata) lausungid, ka pole infot selle kohta, missugused laused on hästi konstrueeritud ja missugused mitte.

Nagu eelkirjeldatust nähtub, on hulk aspekte, mille puhul ei saa alati väita, et keeleline sisend peegeldub keelelises väljundis. Olgu siinkohal esitatud mõningad näited selle väite illustreerimiseks:

- direktiivsus - kuna lapse päeva juhib täiskasvanu, siis see tõsiasi põhjendab, miks täiskasvanu kõnes esineb rohkem direktiive kui lapse omas, ehkki on tõendeid, et teatud arenguetapil või kindlas suhtlussituatsioonis võib lapse kõne olla ka märgatavalt direktiivsem (Argus, ilmumas). Kui kahe täiskasvanu vestluses esines vaid üksikuid direktiive, siis lapsele suunatud kõnes olid ligi pooled kõigist lausungitest direktiivid (Kõrgesaar 2014b);

- $\quad$ küsimused ja kordused - ka neid on hoidjakeeles rohkem kui lapse keeles. Nagu direktiivegi, võib teatud arenguetapil esineda lapse kõnes rohkem küsimusi, kuid nende küsimuste eesmärk on erinev: lapse küsimused on peaaegu 
eranditult infot otsivad (Kõrgesaar 2014a). Sama lugu on kordustega: väikese lapsega kõneldes on korduste eesmärk lapsele asju aina (eri variatsioonidega) üle korrata, et need kinnistuksid, suurema lapsega rääkides kasutatakse kordusi, et anda tagasisidet, et lapse öeldu on õige (Kõrgesaar 2008);

- keelelise sisendi olemus - hoidjakeel ei ole standardne, vaid eri vanemate lastele suunatud kõne morfoloogiliste, leksikaalsete ja süntaktiliste vormide esinemissagedus on isesugune. See mõjutab laste öeldavat ehk keelelist väljundit, sest enamasti omandatakse kõige sagedasemad keeleüksused esimesena. Sagedusel on keele omandamisel küll tähtis roll, kuid selle mõju ei ole alati ühesuunaline, nii võib näiteks liitsõnade puhul täheldada, et osa vanemaid kasutab lapsega kõneldes enam liitsõnu kui teised ning lapsele suunatud kõne liitsõnarikkus ei pruugi alati peegelduda lapse kõnes (Argus, Kazakovskaja 2013: 42). Lisaks tuleb märkida, et üsna sageli kõneldakse sagedusest seoses sõnavara omandamisega (Goodman jt 2008, Naigles, Hoff-Ginsberg 1998, Kauschke, Klann-Delious 2007), kuid vaid sõnade omandamist ei saa pidada keele omandamiseks: sõnu tuleb õppida ka kasutama ja aru saama, mis sõna, missuguses vormis, missugusesse konteksti sobib. Niisiis on peale sageduse tähtis ka produktiivsus, lapse enese oskus õpitud sõnu produktiivselt lausungites kasutada (ema-lapse suhtluse korral on võimalik, et laps imiteerib ema öeldut, kuigi ise sama keelevormi veel ei kasuta. Kui analüüsida lapse suhtlust eakaaslastega, on paremini näha, milliseid keelekonstruktsioone selles vanuses lapsed ise kasutavad, vt Pajusalu jt 2011: 144);

- $\quad$ keelelise sisendi ja sageduse juures on oluline märkida sedagi, et lastekeel on varajases staadiumis väga suurel määral konservatiivne, mis tähendab, et vaid 10\% lausungitest pole järele korratud, vaid on lapse enese loodud, üle poole lausungitest oli vanema kõnes varem samal kujul kasutatud (Lieven jt 2003). Seega on sisendkeelel ja sagedusel hea mõju sõnavara omandamisele, kuid produktiivsust see alati ei põhjusta. Laps valib ise need keelelised vahendid, mida suhtluseks vajab, mistõttu sisendkeel on oluline, kuid mitte ainumäärav (Pajusalu jt 2011: 143, 152);

- ema intonatsioon lapse kõnes enamasti ei peegeldu. Ka siin on küsimus pragmaatikas: kui on öeldud, et ema hääletoon on justkui konks, millega beebi tähelepanu püüda ja see endale fokuseerida (Gopnik jt 1999), siis lapsel pole selleks enamasti vajadust, vaid ta demonstreerib oma tuju või annab oma vajadustest märku kilgete või nutuga;

- lausungite pikkus ja suurem sõnavara - on küll uuritud ja leitud (van Houten 1986), et neil emadel, kelle sõnavara on rikkalikum ja kes räägivad lapsega rohkem, on sageli ka keeleliselt võimekamad lapsed, ent see pole nii kogu aeg. Teatud arenguetapil võib laiema ja keerukama sõnavaraga vanemate laste kõne koguni peetuda (Réger 1990);

- $\quad$ kõne selgus - täiskasvanult väikelapsele suunatud kõne on (enamasti) väga arusaadav, puhaste pikendatud vokaalidega ja liialdatult ilmekas (Gopnik jt 1999). Keeleomandamise varases etapis ei ole aga laste endi kõne sugugi selge, pigem võib kõrvalisel inimesel olla sageli võrdlemisi keeruline lapse lausungit mõista.

Niisiis kombineeruvad lastekeele ja hoidjakeele dünaamika eri aspektid keelt omandava lapse eri vanuses üsna mitmekesisel viisil, pakkudes emba-kumba keelevarianti 
uurivatele keeleteadlastele jätkuvalt ainest, et kirjeldada keelenähtusi, mis mõlemas keelevariandis esinevad, veelgi täpsemini.

Hoidjakeel ja lastekeel mõjutavad vastastikku üksteist, olles tihedalt seotud. Keeleline väljund on keeleomandamise tulemus, mis luuakse vastastikuses suhtluses. Suhtluse algatab keeles ja kultuuris pädevam, kes pakub keeleomandamiseks vajalikke toetuspunkte, kuid ka laps ise on aktiivne osaline, olles suhtluseks valmis sünnist peale. Erinevus noorema ja vanema keelekogukonna liikme vahel seisneb eri suhtlusvahendite (pilgud, häälitsused, žestid, sõnad, fraasid jts) valdamise astmes. Lapse kõne mõjutab seda kõnevarianti, mida kasutab vanem, ja vastupidi - see suhtlus on multimodaalne. Kogenumad keelekasutajad juhivad keele omandamisel nooremaid, andes neile koos sõnade vormiga teada sõnade tähenduse ja nende eri suhtluskontekstides kasutamise sobilikkuse või mittesoovitavuse. Olles ise mõjutatud kultuurinormidest, vahendavad kogenud keelekasutajad neid sisendkeele kaudu ka lapsele. Uurida hoidjakeele ja lastekeele sisu ning seda, mil määral need kattuvad, pole kunagi lihtne olnud, kuid keeleteadlane ja psühholingvist Steven Pinker (1995: 137) võtab selle keeruka valdkonna uurimisvõimalused kokku: kuigi keeleomandamine, nagu kõik tunnetusprotsessid, on lõppkokkuvõttes ikkagi nagu must kast, teame me küllaldaselt selle keelelisest sisendist ja keelelisest väljundist, et olla võimelised tegema täpseid oletusi nende sisu kohta.

\section{Kokkuvõte}

Keel on kompleksne süsteem ja arusaamine selle omandamisest on paljuski ebatäielik. Laias laastus on siiani vastamata küsimused selle kohta, kuidas täpselt laps keelt omandab. Me võime ainult oletada, kuidas ta õpib sõnu ühtlasest kõnevoolust eristama ja hakkab häälikutest sõnu moodustama, mismoodi omandab grammatika või hakkab mõistma semantikat, ja nii jääbki meil peaasjalikult üle vaid spekuleerida. Muidugi on uurijail võimalus teha keelekatseid, korraldada eksperimente, uurida päevikumärkmeid või ka last ennast laboritingimustes, ent alati peab meeles pidama, et nii nagu sisendkeel, ei ole ka laps n-ö konstantne suurus, iga laps on individuaalne ja niisugust nähtust nagu "keskmine laps" ei ole olemas.

Artiklis on kirjeldatud hulka faktoreid, mis keelelist sisendit mõjutavad. Olulisimaks mõjuteguriks peavad autorid kultuurilisi eripärasid, mis määravad esmalt, kas lapsega üldse räägitakse ning kes (vanemad, õed-vennad, teised kogukonna liikmed) ja millal (enne sündi, alates sünnist, alates sellest, kui laps suudab ise esimesi sõnu öelda või kui suudab kahesõnalisi lausungeid moodustada) seda teeb. Samuti määrab kultuuritaust, kas lapsele suunatud kõne on hoidjakeelne (lihtsustatud ja suupärastatud) või mitte ja missuguseid vestlusstrateegiaid kasutatakse (elemasõna kalulidel, lapse eest kõnelemine Lääne-Samoas, lapse pidev ja intensiivne "arendamine", liigne direktiivsus vm).

Kokkuvõtvalt võib öelda, et suur hulk keelenähtusi, mis lapse kõnes ei kajastu, on põhjustatud pragmaatikast - lapse suhtlusel täiskasvanuga on hoopis teistsugune eesmärk ja selleks vajab ta teistsuguseid keelelisi vahendeid kui täiskasvanu. Kui täiskasvanu püüab last õpetada ja tema päeva sisustada (kõnes on sagedased kordused, vestlusküsimused, palved, käsud-keelud jm), siis lapse eesmärk on saada infot (infoküsimused) ja saada oma vajadused-soovid rahuldatud (otsesed 
käsud). Sama puudutab sõnavara tasandit: on keelendeid (nt onomatopoeetilised sõnad, imitatiivid, deminutiivid), mille hulk vanema kõnes kahaneb lapse kasvades ja sama suundumus peegeldub ka lapse enda kõnes. Teisalt on jällegi laste kõne enamasti võrdlemisi nimisõnakeskne ja siinkohal ei saa alati tõmmata paralleele täiskasvanu kõnega.

\section{Viidatud kirjandus}

Argus, Reili 2004. Eesti keele käändesüsteemi omandamine: esimestest sõnadest miniparadigmadeni. - Emakeele Seltsi aastaraamat, 49 (2003), lk 23-49.

Argus, Reili 2008. Eesti keele muutemorfoloogia omandamine. Tallinna ülikooli humanitaarteaduste dissertatsioonid 19. Tallinn: TLÜ Kirjastus.

Argus, Reili, ilmumas. Acquisition of directives in Estonian. - Acquisition of Requests. Eds. Maria Voeikova, Ursula Stephany, Ayhan Aksu-Koç. Mouton de Gruyter.

Argus, Reili; Kazakovskaja, Viktoria 2013. Acquisition of compounds in Estonian and Russian: Frequency, productivity, transparency and simplicity effect. - Eesti Rakenduslingvistika Ühingu aastaraamat, 9, 23-42. http://dx.doi.org/10.5128/ERYag.02

Argus, Reili; Kõrgesaar, Helen 2014. Sõnaliigid eesti lapse kõnes ja lapsele suunatud kõnes. Eesti Rakenduslingvistika Ühingu aastaraamat, 10, 39-53. http://dx.doi.org/10.5128/ ERYa10.03

Bavin, Edith 1992. The acquisition of Walpiri as a first language. - D. I. Slobin (Ed.), The Crosslinguistic Study of Language Acquisition, Vol. III. Hillsdale, NJ: Erlbaum, 309-371.

Behrens, Heike 2006. The input-output relationship in first language acquisition. - Language and Cognitive Processes, 21 (1/2/3), 2-24.

Behrens, Heike 2009. Usage based and emergentist approaches to language acquisition. Linguistics, 47 (2), 383-411. http://dx.doi.org/10.1515/LING.2009.014

Blount, Benjamin G. 1977. Etnography and caretaker - child interaction. - Catherine Snow, Charles Ferguson (Eds.), Talking to Children: Language Input and Acquisition. Cambridge: Cambridge University Press, 296-308.

Boggs, Stephen T. 1985. Speaking, Relating and Learning: A Study of Hawaiian Children at Home and at School. Norwood, NJ: Ablex.

Bonvillain, Nancy 2003. Language, Culture and Communication: The Meaning of Messages. Upper Saddle River, NJ: Prentice Hall.

Bowerman, Melissa 1978. Semantic and syntactic development: A review of what, when, and how in language acquisition. - R. L. Schiefelbusch (Ed.), Bases of Language Intervention. Baltimore: University Park Press, 97-189.

Chouinard, Michelle M.; Clark, Eve V. 2003. Adult reformulations of child errors as negative evidence. - Journal of Child Language, 30 (3), 637-669. http://dx.doi.org/10.1017/ S0305000903005701

Cooper, Robin N.; Aslin, Richard N. 1990. Preference for infant-directed speech in the first month after birth. - Child Development, 61 (5), 1584-1595. http://dx.doi. org $/ 10.2307 / 1130766$

Crago, Martha B.; Annahatak, Betsy; Ningiuruvik, Lizzie 1993. Changing patterns of language socialization in Inuit homes. - Anthropology and Education Quarterly, 24 (3), 205-205. http://dx.doi.org/10.1525/aeq.1993.24.3.05xo968f

Crago, Martha B.; Shanley, E. M. Allen 1998. Acquiring Inuktitut. - O. Taylor, L. Leonard (Eds.), Language Acquisition Across North America: Cross-Cultural and CrossLinguistic Perspectives. San Diego, CA: Singular, 245-279.

Ferguson, Charles A. 1977. Baby talk as simplified register. - Catherine E. Snow, Charles A. Ferguson (Eds.), Talking to Children: Language Input and Acquisition. Cambridge University Press, 219-235. 
Fernald, Anne 1985. Four-month-old infants prefere to listen to motherese. - Infant Behavior and Development, 8 (2), 181-195. http://dx.doi.org/10.1016/S0163-6383(85)80005-9

Fernald, Anne; Taeschner, Traute; Dunn, Judy; Papousek, Mechthild; de Boysson-Bardies, Bénédicte; Fukui, Ikuko 1989. A cross-language study of prosodic modifications in mother's and father's speech to preverbal infants. - Journal of Child Language, 16 (3), 477-501. http://dx.doi.org/10.1017/S0305000900010679

Fromkin, Viktoria; Rodman, Robert; Hyams, Nina 2011 [2003]. An Introduction to Language. Wadsworth CENGAGE Learning.

Gaskins, Suzanne 1999. Children's daily lives in a Mayan village: A case study of culturally constructed roles and activities. - A. Goncu (Ed.), Children's Engagement in the World. Cambridge: Cambridge University Press, 25-81.

Goodman, Judith C.; Dale, Philip S.; Li, Ping 2008. Does frequency count? Parental input and the acquisition of vocabulary. - Journal of Child Language, 35 (3), 515-531. http:// dx.doi.org/10.1017/So305000907008641

Gopnik, Alison; Meltzoff, Andrew; Kuhl, Patricia 1999. The Scientist in the Crib: Minds, Brains, and How Children Learn. William Morrow \& Co.

Hennoste, Tiit 2002. Keelekasutuse uurimine. - Emakeele Seltsi aastaraamat, 48 (2001), 217-262.

Heath, Shirley B. 1989. Oral and literate traditions among Black Americans living in poverty. - American Psychologist, 44 (2), 367-373. http://dx.doi. org/10.1037/0003-066X.44.2.367

Hoff-Ginsberg, Erika 1998. The relation of birth order and socioeconomic status to children's language experience and language development. - Applied Psycholinguistics, 19 (4), 603-629. http://dx.doi.org/10.1017/So142716400010389

Kauschke, Christina; Hofmeister, Christoph 2002. Early lexical development in German: A study on vocabulary growth and vocabulary composition during the second and third year of life. - Journal of Child Language, 29 (4), 735-757. http://dx.doi.org/10.1017/ $\underline{\text { So305000902005330 }}$

Kauschke, Christina; Klann-Delius, Gisela 2007. Characteristics of maternal input in relation to vocabulary development in children learning German. - Insa Gülzow, Natalia Gagarina (Eds.), Frequency Effects in Language Acquisition: Defining the Limits of Frequency as an Explanatory Concept. De Gruyter Mouton, 181-204. http://dx.doi. org/10.1515/9783110977905.181

Kõrgesaar, Helen 2008. Hoidjakeelele omastest joontest ning selle dünaamikast. Bakalaureusetöö. Tallinn: Tallinna Ülikool.

Kõrgesaar, Helen 2014a. Küsimused eesti lapsele suunatud kõnes leedu ja vene keele taustal. - Eesti Rakenduslingvistika Ühingu aastaraamat, 10, 193-207. http://dx.doi. org/10.5128/ERYa10.12

Kõrgesaar, Helen 2014b. Eesti isade-emade hoidjakeel: kes küsib, kes käsutab, kes räägib rohkem? - Tallinna Ülikooli Eesti keele ja kultuuri instituudi toimetised, 16, 59-82.

Kõrgesaar, Helen; Kapanen, Airi 2015. Kui lapsega ei räägi üksnes ema: valik termineid lasteja hoidjakeele kohta. - Eesti Rakenduslingvistika Ühingu aastaraamat, 11, 177-188. http://dx.doi.org/10.5128/ERYa11.11

Levelt, Willem Johannes Maria (Pim) 1975. What became of LAD? - W. Abraham (Ed.), Ut Vidaeum: Contributions to an Understanding of Linguistics. Atlantic Highlands, NJ: Humanities, 171-190.

Lieven, Elena 1994. Crosslinguistic and crosscultural aspects of language addressed to children. - Claire Gallaway, Brian J. Richards (Eds.), Input and Interaction in Language Acquisition. Cambridge: Cambridge University Press, 56-73.

Lieven, Elena 2010. Input and first language acquisition: Evaluating the role of frequency. Lingua, 120 (11), 2546-2556. http://dx.doi.org/10.1016/j.lingua.2010.06.005 
Lieven, Elena; Tomasello, Michael; Behrens, Heike; Speares, Jennifer 2003. Early syntactic creativity: A usage-based approach. - Journal of Child Language, 30 (2), 333-370. http://dx.doi.org/10.1017/S0305000903005592

Lieven, Elena; Stoll, Sabine 2013. Early communicative development in two cultures: A comparison of the communicative environments of children from two cultures. - Human Development, 56 (3), 178-206. http://dx.doi.org/10.1159/000351073

Naigles, Letitia R; Hoff-Ginsberg, Erika 1998. Why are some verbs learned before others? Effects of input frequency and structure on children's early verb use. - Journal of Child Language, 25 (1), 95-120.

Newport, Elissa L. 1976. Motherese: The speech of mothers to young children. - N. Castellan, D. Pisoni, G. Potts (Eds.), Cognitive Theory, Vol. 2. Hillsdale, NJ: Erlbaum, 177-217.

Newport, Elissa L.; Gleitman, Henry; Gleitman, Lila R. 1977. Mother I'd rather do it myself: Some effects and non-effects of maternal speech style. - Catherine E. Snow, Charles A. Ferguson (Eds.), Talking to Children: Language Input and Acquisition. Cambridge University Press, $109-150$.

Ninio, Anat 1992. The relation of children's single word utterances to single word utterances in the input. - Journal of Child Language, 19 (1), 87-110. http://dx.doi.org/10.1017/ S0305000900013647

Ninio, Anat 2011. Syntactic Development, Its Input and Output. New York: Oxford University Press Inc. http://dx.doi.org/10.1093/acprof:oso/9780199565962.001.0001

Ochs, Elinor 1991. Misunderstanding children. - N. Coupland, H. R. Giles, J. M. Wieman (Eds.), Miscommunication and Problematic Talk. Newberry Park, CA: Sage, 44-6o.

Ochs, Elinor; Schieffelin, Bambi 1994. The impact of language socialization on grammatical development. - P. Fletcher, B. MacWhinney (Eds.), The Handbook of Child Language. Blackwell, 73-94.

Pajusalu, Karl 2001. Baby talk as a sophisticated register: A phonological analysis of South Estonian. - Psychology of Language and Communication, 5 (2), 81-92.

Pajusalu, Renate; Tõugu, Pirko; Vija, Maigi; Tulviste, Tiia 2011. Konditsionaali omandamisest lastekeeles. - Eesti Rakenduslingvistika Ühingu aastaraamat, 7, 141-155. http:// dx.doi.org/10.5128/ERYa7.09

Pinker, Steve 1995. Language acquisition. - Daniel N. Osheron, Lila R. Gleitman (Eds.), An Invitation to Cognitive Science, Vol. 1: Language. Cambridge, MA: MIT Press, 135-182.

Pye, Clifton 1986. Quiché Mayan speech to children. - Journal of Child Language, 13 (1), 85-100. http://dx.doi.org/10.1017/s0305000900000313

Pye, Clifton 1992. The acquisition of K'iche Maya. - D. I. Slobin (Ed.). The Crosslinguistic Study of Language Acquisition, Vol. 3. Hillsdale, NJ: Erlbaum, 221-308.

Rabain-Jamin, Jacqueline 1994. Language and socialization of the child in African families living in France. - Patricia M. Greenfield, Rodney R. Cocking (Eds.), Cross-Cultural Roots of Minority Child Development. Hillsdale, NJ: Lawrence Erlbaum Associates, 147-166.

Réger, Zita 1990. Mother's speech in different social groups in Hungary. - Gina Conti-Ramsden, Catherine E. Snow (Eds.), Children's Language, Vol. 7. Hillsdale, NJ: Erlbaum Ass., 197-222.

Schieffelin, Bambi B. 1985. The acquisition of Kaluli. - D. I. Slobin (Ed.), The Crosslinguistic Study of Language Acquisition, Vol. 1. Hillsdale, NJ: Erlbaum, 525-593.

Schieffelin, Bambi B. 1990. The give and take of everyday life: Language socialization of Kaluli children. Cambridge: Cambridge University Press.

Scollon, Suzanne B. K. 1982. Reality set, socialization and linguistic convergence. PhD dissertation. University of Hawaii.

Soderstrom, Melanie; Wittebolle, Kelsey 2013. When do caregivers talk? The influences of activity and time of day on caregiver speech and child vocalizations in two 
childcare environments. - PLoS One, November 18. http://dx.doi.org/10.1371/journal.pone.0080646

Stolt, Suvi; Korja, Riikka; Matomägi, Jaakko; Lapinleimu, Helena; Haataja, Leena; Lehtonen, Liisa 2014. Early relations between language development and the quality of motherchild interaction in very-low-birth-weight children. - Early Human Development, 90 (5), 219-225. http://dx.doi.org/10.1016/j.earlhumdev.2014.02.007

Strömqvist, Sven 1984. Make-Believe Through Words: A Linguistic Study of Children's Play with a Doll's House. Gothenburg Monographs in Linguistics 4. University of Gothenburg: Department of Linguistics.

Toivainen, Kirsti 1994. Hoivakielen tutkimuksesta ja suomen murteiden hoivasanastosta. - Kirsti Toivainen, Jorma Toivainen (Toim.), Ensikielenä suomalaiskieli. Turun yliopiston suomalaisen ja yleisen kielitieteen laitoksen julkaisuja 46. Turku, 42-49.

Tomasello, Michael 2005. Constructing a Language. A Usage-Based Theory of Language Acquisition. Harvard University Press.

van Houten, Lori 1986. The role of maternal input in the acquisition process: The communicative strategies of adolescent and older mothers with their language learning children. - Paper presented at the Boston University Conference on Language Development, Boston. http://files.eric.ed.gov/fulltext/ED291236.pdf (9.3.2016).

Wang, Yuanyuan; Seidl, Amanda; Cristia, Alejandrina 2015. Acoustic-phonetic differences between infant- and adult-directed speech: The role of stress and utterance position. - Journal of Child Language, 42 (4), 821-842. http://dx.doi.org/10.1017/ $\underline{\text { S0305000914000439 }}$

Wanner, Eric; Gleitman, Lila R. 1982. Language Acquisition: The State of the Art. Cambridge University Press.

Wood, Donna; Bruner, Jerome; Ross, Gail 1976. The role of tutoring in problem-solving. - Journal of Child Psychology and Psychiatry, 17 (2), 89-100. http://dx.doi. org/10.1111/j.1469-7610.1976.tboo381.x

\author{
Helen Kõrgesaar (Tallinna Ülikool) uurib eesti hoidjakeelt, selle dünaamikat ja mõju lapse \\ kõne arengule. \\ Narva mnt 25, 10120 Tallinn, Estonia \\ helen.korgesaar@gmail.com
}

Airi Kapanen (Tallinna Ülikool) uurib eesti laste keeleomandamist, täpsemini süntaksi arengut ja komplekssust.

Narva mnt 25, 10120 Tallinn, Estonia

airikapanen@gmail.com 


\title{
WHERE DOES THE CHILD GET THOSE SONGS: LINGUISTIC INPUT AND OUTPUT UNDER THE MICROSCOPE
}

\author{
Helen Kõrgesaar, Airi Kapanen
}

Tallinn University

The article discusses the qualitative and functional peculiarities of caregiver speech and child speech, the importance of the way in which children are spoken to, and whether input language has an important role in speech development. Also, an overview is provided of the nature and essential features of input language, presenting the similarities and differences between input and output and describing the ways in which different factors affect the way in which children are interacted with, including child-directed speech.

As children acquire language in a speech community, with different social situations and with interlocutors whose language exhibits varying degrees of phonological, morphological, syntactic and semantic competence, child-directed speech is dynamic and changes as the child matures. The form of child-directed speech is considered to play an important role in children's language development, and a number of linguistic features that appear during certain time periods in child-directed speech are also reflected in the child's own speech. However, there are also linguistic features that, while present in adult speech, do not appear at all in child speech.

Caregiver speech is often taken to mean only the speech of a mother to her child, but in fact the term denotes any speech that a child hears, whether the speaker is the mother or someone else close to the child and whether or not the speech is directed at the child. Broadly speaking, the process of language acquisition has two participants, one of whom - the child - takes in what is offered. Over time the child, having lived under the influence of linguistic input, also begins to offer something, which we term linguistic output. There are a number of articles (e.g. Ninio 2011, Behrens 2006, 2009, Lieven 2010) devoted to the study of the interaction between child speech and child-directed speech, wherein, in order to emphasize the distinctive features of both, they are compared to the notion of "normal language", thus implying that both child speech and child-directed speech are perceived as being quite different from ordinary language use.

The primary question is whether children might miss out on something important when hearing a simplified form of language, as they have to be able to acquire complex levels of language and apply them in different social situations. Since caregiver speech is a language form that is adapted to be more accessible to the child, how does the child, relying on this simplified form, learn to produce more complex phonological sequences, ways of combining words and expressions, etc., considering that at the same time, the child must also learn to properly segment words and expressions from the flow of input speech and to connect the phonological forms of words to their meanings?

The relationship between linguistic input and output remains unclear to researchers of child and caregiver speech, as well as to developmental psychologists 
who have studied it in depth (see Argus, Kõrgesaar 2014, Ninio 2011, Lieven 2010). It is logical to think that if we give a child linguistic input, we obtain linguistic output from the child as a result, but this is a fairly primitive train of thought, since we are dealing with people rather than machines. Eric Wanner and Lila Gleitman (1982: 311) claim that while caregiver speech does have clear distinctive features, it is not clear that these features actually support the child's language acquisition process. According to Melissa Bowermann (1987: 110), it is not necessary for a child's language environment to be anything special and forced in order for the child to acquire the language.

The article describes a number of factors that influence linguistic input. The most important of these are cultural factors that determine whether or not the child is spoken to at all and, if so, by whom (parents, siblings, other members of the community) and when (e.g. before birth, beginning from birth, from when the child begins to say his or her first words or to form two-word sentences). The cultural background also determines whether or not child-directed speech is typical caregiver speech (simplified and adapted to the child's own capabilities) and which types of conversational strategies are used (e.g. the word elema among the Kaluli, adults speaking in place of children in Western Samoa, continual and intensive active "development" of the child, or excessive use of directives).

Thus it can be observed that the absence of numerous linguistic features from child speech can be explained by pragmatics - the child's goals in communicating with adults are different from the adult's goals, and therefore require the use of different linguistic means. Whereas adults try to teach children and occupy their day (using frequent repetition, conversation-starting questions, requests, commands/ prohibitions, etc), the child's goal is to obtain information (information-seeking questions) and have his or her needs and desires satisfied (direct commands). The same applies on the level of lexis: there are certain types of expressions (e.g. onomatopoetic words, imitatives, diminutives) whose frequency in child-directed speech declines as the child grows, and the same tendency is reflected in the child's own speech as well. However, child speech remains relatively noun-centric, and here it is not always possible to draw parallels with adult speech.

Keywords: first language acquisition, child-directed speech, caregiver speech, child language, Estonian 